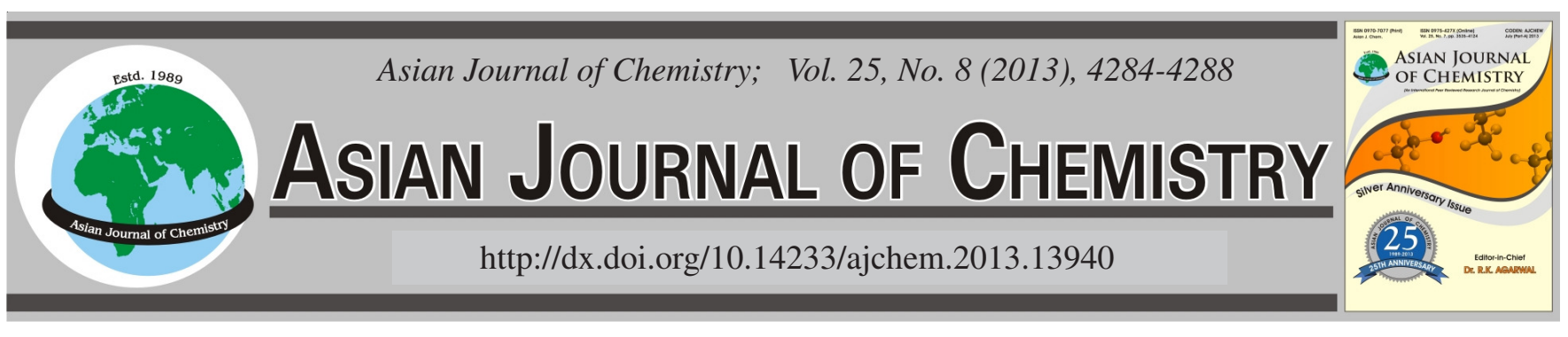

\title{
Adsorption of Lead, Cadmium and Zinc Ions from Industrial Wastewater by Using Raw Clay and Broken Clay-Brick Waste
}

\author{
M.F. El-ShahaT ${ }^{1}$ and A.M.A. SHEHATA ${ }^{2, *}$
}

${ }^{1}$ Department of Chemistry, Faculty of Science, The University of Ain Shams, Abbasia, Cairo 11566, Egypt

${ }^{2}$ Department of Chemistry, Faculty of Education, The University of Suez Canal, Al-Arish 45111, Egypt

*Corresponding author: Fax: +20 55 2319917; Tel: +20 11 18262857; E-mail: ashehataeg@yahoo.com

(Received: 23 April 2012;

Accepted: 9 February 2013)

AJC-12945

\begin{abstract}
This work studies the adsorption process of lead, cadmium and zinc on clay and clay-brick powders. The adsorption process was affected by various parameters, such as contact time, $\mathrm{pH}$ value of metal ions in solutions, the adsorbent mass and metal concentration. The kinetics and the maximum capacity depend on the type of the material ions (atomic weight, atomic radius and electronegativity). The uptake percentage reaches equilibrium state after $160 \mathrm{~min}$ for lead and cadmium and $120 \mathrm{~min}$ for zinc on clay-brick powder, while it reaches the equilibrium state after $140 \mathrm{~min}$ for lead, $160 \mathrm{~min}$ for cadmium and $120 \mathrm{~min}$ for zinc on clay powder. The uptake percentages of $\mathrm{Pb}, \mathrm{Cd}$ and $\mathrm{Zn}$ increases with the increase $\mathrm{pH}$-value. The sequence of adsorption capacities for lead, cadmium and zinc at constant $\mathrm{pH}$ is recorded in the order:lead > cadmium > zinc. The lead, cadmium and zinc removal percentages are, respectively $69,22.7$ and $12.9 \%$, by using clay powder at $\mathrm{pH}=6$; while they are, respectively $77.3,29.48$ and $13.5 \%$, by using clay-brick powder at the same $\mathrm{pH}$.
\end{abstract}

Key Words: Adsorption, Clay, Lead, Cadmium, Zinc.

\section{INTRODUCTION}

Different industrial wastes (particularly, those from mining, electroplating, lead smelting and metal finishing industries), discharge amounts of heavy metals in various forms. The concentration of these heavy metals in wastewater may rise to a level that can be hazardous to live stock. Lead, cadmium and zinc are highly toxic in the environment ${ }^{1,2}$. The precipitation process is usually not sufficient to reduce lead concentration to the level of water quality standards ${ }^{3}$. Treatment processes for lead, cadmium and zinc from water and wastewater through adsorption or ion exchange were studied. Park et $a l .{ }^{4}$ used sargassum [algae] for the removal of lead and cadmium ions from water. Petruzzelli et al. ${ }^{5}$ and Faghihian et $a{ }^{6}{ }^{6}$ used clinoptilolite in the sodium form (natural zeolite) for the removal of lead from battery and nuclear wastewater. Vecchio et al. ${ }^{7}$ studied the removal of $\mathrm{Cu}(\mathrm{II}), \mathrm{Pb}$ (II) and $\mathrm{Cd}(\mathrm{II})$ ions by biosorption on bacterial cells. Srivastav et al. ${ }^{8}$ used the aquatic plants for the removal of lead(II) and zinc(II) ions from wastewater. Niu et al. ${ }^{9}$ studied the adsorption of lead ions on non-living penicillium crysogenum biomass. Pansini et al. ${ }^{10}$ used chabazite as a natural zeolite exchanger for the removal of lead ions from water. Namasivayam et al. ${ }^{11}$ used iron(III) chromium(III) hydroxide as adsorbents. Laumakis et $a l .{ }^{12}$ used fly ash sub-grades for the removal of lead ions from wastewater. Hewitt et al. ${ }^{13}$ used ion exchange columns packed with Amberlite IR-120 resin for the removal of ionic alkyl-lead compounds from aqueous solution. Reed et al. ${ }^{14}$ used granular activated carbon columns for the removal of lead and cadmium ions from aqueous waste streams. ELShahat et al. ${ }^{15}$ used bones and other natural materials for the removal of lead, cadmium and zinc from industrial wastewater. Mehmet Yaman ${ }^{16}$ studied the improvement of sensitivity in lead and cadmium determinations using flame atomic absorption spectrometry. Senkal et al. ${ }^{17}$ studied the removal of cadmium and lead in water samples by using thiourea sulfonamide as a new polymeric sorbent. Benhima et al. ${ }^{18}$ studied the removal of lead and cadmium ions from aqueous solution by adsorption onto micro-particles of dry plants. Maryam et al. ${ }^{19}$ used walnut, hazelnut, almond, pistachio shell and apricot stone for the removal of lead, cadmium and zinc from industrial wastewater. Dong et $a .^{20}$ studied the adsorption of cadmium, copper, zinc and barium from freshwater. Gupta $e t a l .^{21}$ and vengrist et al. ${ }^{22}$ used clay for the removal of nickel, copper and zinc from wastewater. Abdel-Ghani et al..$^{23}$, Cesura et al..$^{24}$, EL-Shahat et al. ${ }^{25,26}$ and Salamatinia et al. ${ }^{27}$ used low-cost natural material and by-products for the removal lead, zinc, cadmium, copper and fluoride from wastewater. Kanquan et al. ${ }^{28}$ used activated carbon fiber from cotton stalk as a natural material for the adsorption of $p$-nitroaniline from 
aqueous solutions. The aim of this work is to study the adsorption of lead, cadmium and zinc on natural materials such as ground clay and clay-brick samples. The effect of adsorbent mass, contact time and $\mathrm{pH}$ value on the uptake percent of these metal ions from their aqueos solutions were studied.

\section{EXPERIMENTAL}

Preparation of the natural materials: Natural clay and broken clay-brick waste were obtained from clay-brick factory. Raw clay was collected before burning, but crushed waste brick were collected after burning by using butane gas cylinder (the same clay ore). The source of clay is Abu-Zabaal quarry at depth from 3-5 m. The two materials were washed with $0.1 \mathrm{~N}$ nitric acid, sulfuric acid, hydrochloric acid, then by distilled water until free from acids and then dried at $100{ }^{\circ} \mathrm{C}$ followed by mechanical sieving to suitable size $(0.2 \mathrm{~mm})$.

Solubility and chemical analysis of the natural materials: The solubility of the two materials was tested with nitric acid solution at different $\mathrm{pH}$ values (from $\mathrm{pH} 1-3$ ) and the loss of weight was $1.5,0.99$ and $0.52 \%$ for clay, respectively and $0.51,0.24$ and $0.11 \%$ for clay-brick, respctively. The complete chemical analysis was given in Table-1. Gravimetric, titrimetric and photometric methods were used in the analysis.

\begin{tabular}{ccc}
\multicolumn{4}{c}{ TABLE-1 } \\
\multicolumn{3}{c}{ CHEMICAL ANALYSIS OF THE TWO SORBENTS } \\
\hline Parameter (\%) & Clay & Clary-brick \\
\hline $\mathrm{H}_{2} \mathrm{O}$ (free) & 3.50 & 1.4 \\
Loss on ignition & 2.11 & 0.09 \\
$\mathrm{SiO}_{2}$ & 84.87 & 87.24 \\
$\mathrm{Fe}_{2} \mathrm{O}_{3}$ & 5.62 & 6.83 \\
$\mathrm{Al}_{2} \mathrm{O}_{3}$ & 1.01 & 1.51 \\
$\mathrm{MgO}$ & 0.32 & 0.56 \\
$\mathrm{CaO}$ & 1.66 & 2.13 \\
$\mathrm{P}_{2} \mathrm{O}_{5}$ & 0.69 & 1.01 \\
$\mathrm{Zn}$ & 0.02 & 0.05 \\
$\mathrm{~Pb}$ & 0.01 & 0.020 \\
$\mathrm{Ni}$ & 0.08 & 0.13 \\
$\mathrm{Cu}$ & 0.02 & 0.034 \\
$\mathrm{Cd}$ & n.d & n.d \\
\hline
\end{tabular}

Adsorption experiments: Batch experiment techniques were used, where a constant volume/mass $(\mathrm{v} / \mathrm{m})$ ratio was used in this technique. A certain weight of the adsorbent $(0.1 \mathrm{~g})$ was mixed with a known volume $(50 \mathrm{~mL})$ of the solution containing lead, cadmium and zinc. The mixture was then agitated at $300 \mathrm{rpm}$ till equilibrium was reached. The liquid phase was separated by decantation or filtration and replaced by the same volume of the initial solution. The procedure of separation and replacement was repeated until saturation was attained. A known volume $(5 \mathrm{~mL})$ of the liquid phase was used for analysis using atomic absorption spectrometry.

Collection and preparation of wastewater samples: The real wastewater samples were collected from Abu Zabaal area (fertilizers and mining industries) and Ahlia area (metallic industries) around Cairo. These samples were filtered, acidified with $\mathrm{HNO}_{3}(0.5 \% \mathrm{v} / \mathrm{v})$ and stored in polyethylene bottles, until the time of analysis.

Preparation of synthetic water samples: Three synthetic water samples with composition similar to wastewater discharging from Abu Zabaal area were prepared. The chemical analysis showed $2.5 \mathrm{mg} / \mathrm{L} \mathrm{Pb}, 1.5 \mathrm{mg} / \mathrm{L} \mathrm{Cd}$ and $2.5 \mathrm{mg} / \mathrm{L} \mathrm{Zn}$ at $\mathrm{pH} 6$.

Calculation of the uptake percentage: The uptake percentage of lead, cadmium and zinc ions on the two adsorbents was calculated using "eqn. 1" and the adsorbed concentration $\mathrm{C}_{\mathrm{r}}$ was calculated using "eqn. 2 ".

$$
\operatorname{Uptake}(\%)=\frac{\mathrm{C}_{0}-\mathrm{C}_{\mathrm{w}}}{\mathrm{C}_{0}} \times 100
$$

where $\mathrm{C}_{0}=$ initial concentration $(\mathrm{mg} / \mathrm{L}), \mathrm{C}_{\mathrm{w}}=$ final concentration $(\mathrm{mg} / \mathrm{L})$.

$$
\mathrm{C}_{\mathrm{r}}=\mathrm{C}_{0}-\mathrm{C}_{\mathrm{w}}(\mathrm{mg} / \mathrm{L})
$$

The instrument used for determination of lead, cadmium and zinc is a Pye-Unicam model PU 4100 atomic absorption spectrophotometer and flask shaker, (Gallen Kamp with timer No. SGL 700) was used. Muffle furnace (Heareaus type Mir 170E) and electrical furnace, (type 50 No. 139) were also used. $\mathrm{Pb}(\mathrm{II}), \mathrm{Cd}(\mathrm{II})$ and $\mathrm{Zn}$ (II) metal cations were brought to the adsorbate particle contact as $\mathrm{Pb}\left(\mathrm{NO}_{3}\right)_{2}, \mathrm{CdCl}_{2} \cdot \mathrm{H}_{2} \mathrm{O}$ and $\mathrm{ZnCl}_{2}$. The salts dissolved in water and were analytical grade reagents from Fluka. Aqueous solutions of there salts were prepared with deionized water. The main characteristics of all ions being summarized in Table- $2^{18}$.

\section{RESULTS AND DISCUSSION}

The average concentrations of lead, cadmium and zinc has been determined in wastewater samples collected from Abu Zabaal and Ahlia area around Cairo (during 6 months). The results indicated to Abu Zabaal samples (pH6) contained $2.6 \mathrm{mg} / \mathrm{L} \mathrm{Pb}, 0.52 \mathrm{mg} / \mathrm{L} \mathrm{Cd}$ and $2.51 \mathrm{mg} / \mathrm{L} \mathrm{Zn}$ and contained $1.54 \mathrm{mg} / \mathrm{L} \mathrm{Pb}, 0.32 \mathrm{mg} / \mathrm{L} \mathrm{Cd}$ and $1.04 \mathrm{mg} / \mathrm{L} \mathrm{Zn}$ for Ahlia samples ( $\mathrm{pH} 7.3)$.

Determination of $\mathbf{v} / \mathbf{m}$ ratio: The ratio of the volume of the aqueous phase to the weight of sorbent $(\mathrm{v} / \mathrm{m})$ represents an important parameter in the adsorption process. Different

\begin{tabular}{|c|c|c|c|}
\hline \multicolumn{4}{|c|}{$\begin{array}{c}\text { TABLE-2 } \\
\text { MAIN PROPERTIES OF ADSORBATES }\end{array}$} \\
\hline Property & $\mathrm{Pb}(\mathrm{II})$ & $\mathrm{Cd}(\mathrm{II})$ & $\mathrm{Zn}(\mathrm{II})$ \\
\hline Atomic weight $(\mathrm{g} / \mathrm{mol})$ & 207.2 & 112.41 & 65.38 \\
\hline Salt used to prepare the ionic solutions & $\mathrm{Pb}\left(\mathrm{NO}_{3}\right)_{2}$ & $\mathrm{CdCl}_{2} \cdot \mathrm{H}_{2} \mathrm{O}$ & $\mathrm{ZnCl}_{2}$ \\
\hline Purity (\%) & 98.5 & 98 & 98.5 \\
\hline Solubility of the salt $(\mathrm{mol} / \mathrm{L})$ & 1.57 & 6.95 & 66 \\
\hline Cation radius $(\AA)$ & 1.20 & 0.97 & 1.39 \\
\hline Charge density $\left(10^{\circ} \mathrm{C} / \mathrm{m}\right)$ & 4.30 & 3.68 & 3.91 \\
\hline Pauling electronegativity & 1.87 & 1.69 & 1.65 \\
\hline
\end{tabular}
weights of adsorbent powders were shaken with $50 \mathrm{~mL}$ of 
lead, cadmium and zinc solutions $(1 \mathrm{mg} / \mathrm{L})$ for $2 \mathrm{~h}$. The results showed that the highest uptake percentage was at $0.1 \mathrm{~g}$ at $\mathrm{pH}$ $=6$. The $\mathrm{v} / \mathrm{m}$ ratio has been found to be $500 \mathrm{~mL} / \mathrm{g}$.

Factors affecting adsorption process: The adsorption process of lead, cadmium and zinc by using the two adsorbents was affected by various parameters, such as, mass of adsorbent, contact time, $\mathrm{pH}$ value of the solution and concentration of metals.

Effect of adsorbent mass: The effect of adsorbent mass was studied by shaking certain masses $(0.025,0.050,0.100$, 0.200 and $0.300 \mathrm{~g}$ ) of the adsorbent with $50 \mathrm{~mL}$ of $1 \mathrm{mg} / \mathrm{L}$ metal ion solution over night, at $\mathrm{pH}$ value $=4$ and the uptake percentage was determined for each adsorbent mass. Figs. 1 and 2 indicate that the highest constant uptake percentage was achieved at mass of $0.1 \mathrm{~g}$ of both adsorbents.

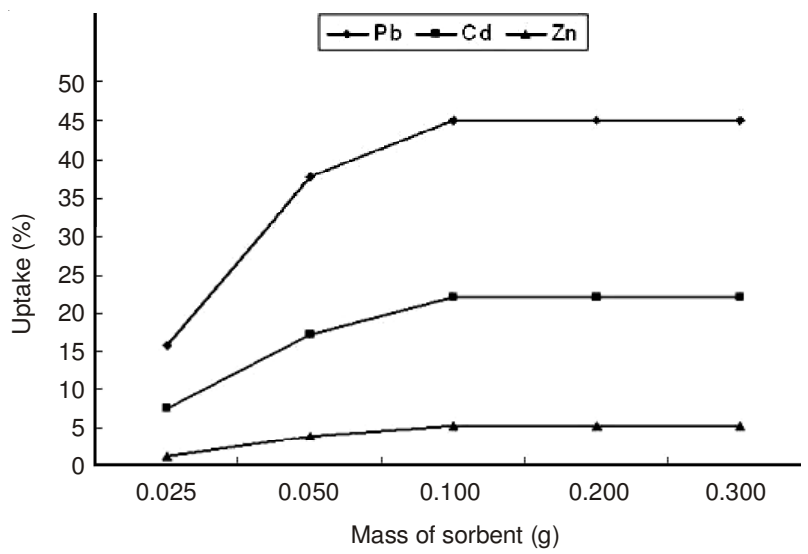

Fig. 1. Effect of adsorbent mass on the uptake per cent of lead, cadmium and zinc at $\mathrm{pH}=4$ by shaking their solutions $(1 \mathrm{mg} / \mathrm{L})$ with clay powder overnight

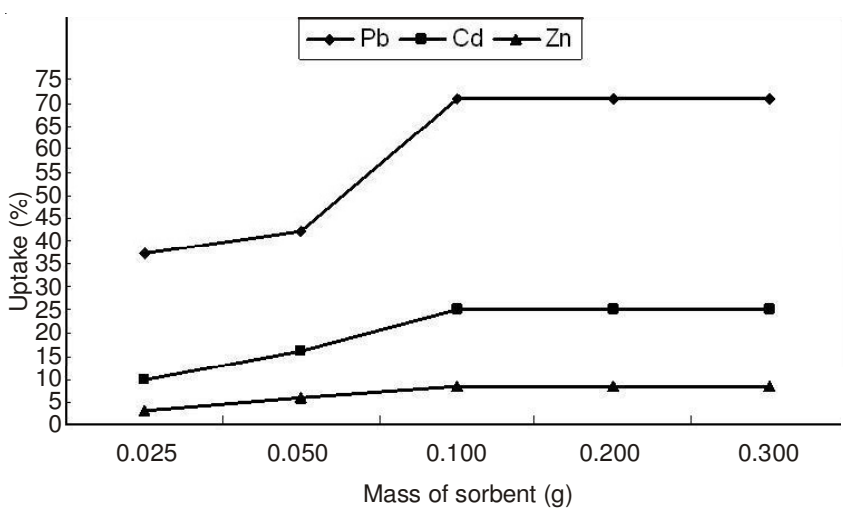

Fig. 2. Effect of adsorbent mass on the uptake per cent of lead, cadmium and zinc at $\mathrm{pH}=4$ by shaking their solutions $(1 \mathrm{mg} / \mathrm{L})$ with claybrick powder overnight

Effect of contact time: The effect of the time of adsorption of lead, cadmium and zinc on clay and clay-brick powders was studied by using solutions $(1 \mathrm{mg} / \mathrm{L})$ of $\mathrm{Pb}^{2+}, \mathrm{Cd}^{2+}$ and $\mathrm{Zn}^{2+}$ at $\mathrm{pH}=4$ with a $\mathrm{v} / \mathrm{m}$ ratio of $500 \mathrm{~mL} / \mathrm{g}$. The relation between the shaking time and uptake percentage of each metal ion by using clay powder is shown in Fig. 3. The uptake percentage reached the equilibrium state after $140 \mathrm{~min}(45 \%)$, $160 \mathrm{~min}(22.1 \%) 120 \mathrm{~min}(5.2 \%)$, for lead, cadmium and zinc ions, respectively. The relation between the shaking time and uptake percentage of lead, cadmium and zinc by using

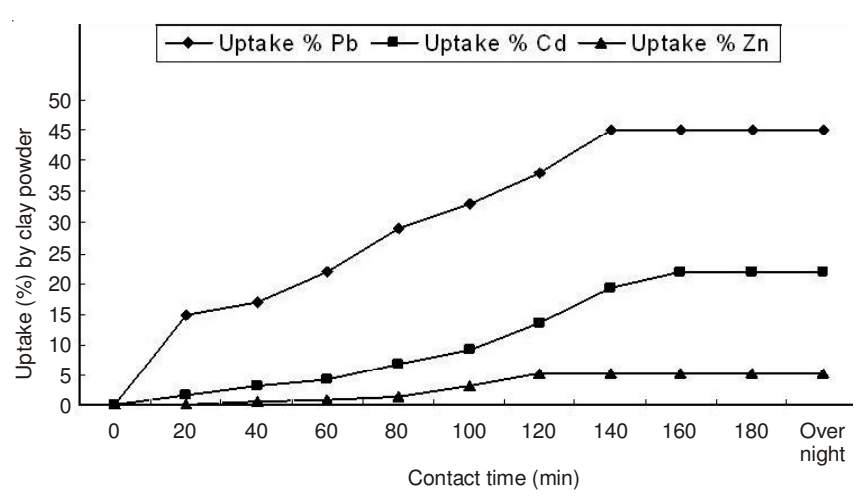

Fig. 3. Effect of contact time on uptake per cent of lead, cadmium and zinc from their solutions $(1 \mathrm{mg} / \mathrm{L})$ by clay powder using $\mathrm{v} / \mathrm{m}$ ratio of $500 \mathrm{~mL} / \mathrm{g}$ at $\mathrm{pH}=4$

clay-brick powder is shown in Fig. 4. The uptake percentage reached the equilibrium state after $160 \mathrm{~min}(71 \%), 160 \mathrm{~min}$ $(25.1 \%)$ and $120 \mathrm{~min}(8.5 \%)$ for lead, cadmium and zinc ions, respectively.

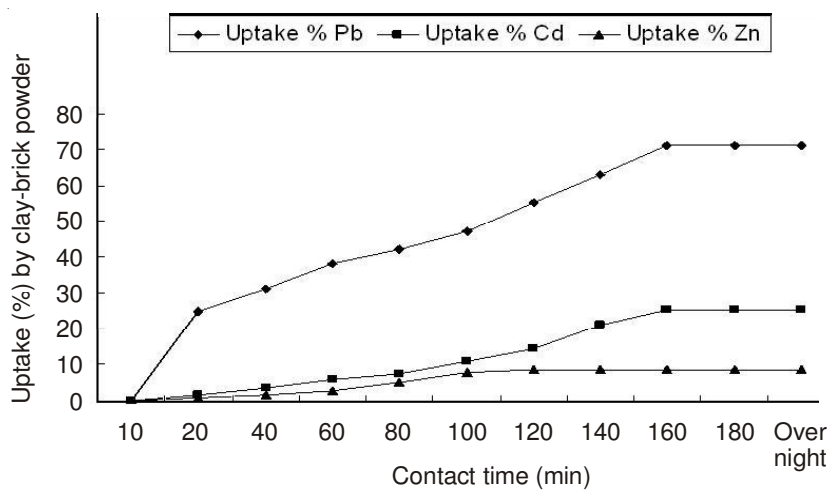

Fig. 4. Effect of contact time on uptake per cent of lead, cadmium and zinc from their solutions $(1 \mathrm{mg} / \mathrm{L})$ by clay-brick powder using $\mathrm{v} / \mathrm{m}$ ratio of $500 \mathrm{~mL} / \mathrm{g}$ at $\mathrm{pH}=4$

Effect of pH: The effect of $\mathrm{pH}$ on the uptake percentage of lead, cadmium and zinc from their solutions $(1 \mathrm{mg} / \mathrm{L})$ by using the two adsorbents was studied. Figs. 5 and 6 show the effect of $\mathrm{pH}$ on the uptake percentage of lead, cadmium and zinc from their solutions $(1 \mathrm{mg} / \mathrm{L})$ by using clay and claybrick powders, respectively. Accordingly, the uptake percentages of lead, cadmium and zinc increase with the increase of the $\mathrm{pH}$ value. The sequence of uptake percent of the metals on the two adsorbents appears in the following order $\mathrm{Pb}>\mathrm{Cd}>$ $\mathrm{Zn}$.

The results also showed that the adsorption capacity of clay-brick is higher than that of clay. Therefore, the fired clay bricks possess higher efficiency for the removal of these heavy metal ions from wastewater; this fact reflects the activation of clay by firing at higher temperatures $\left(700-800^{\circ} \mathrm{C}\right)$.

Effect of initial metal ion concentration: At equilibrium (after $9 \mathrm{~h}$ of contract time) the remaining metal concentration in each case was measured, the results are displayed in Fig. 7 for $\mathrm{Pb}(\mathrm{II}), \mathrm{Cd}(\mathrm{II})$ and $\mathrm{Zn}$ (II) by using clay-brick powder. As shown in the figure the change of the initial metal ion, concentration has a significant effect on the uptake efficiency. These results indicate that the metal ions uptake tends to saturate as the initial concentration is increased. This can be 


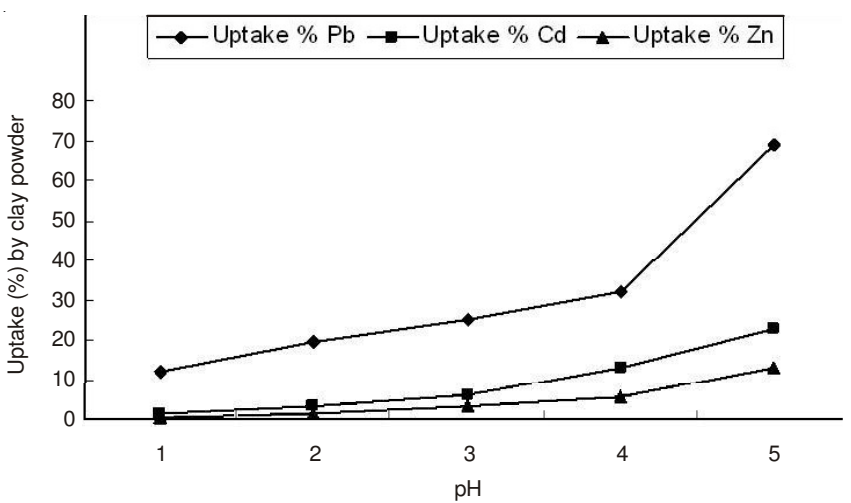

Fig. 5. Effect of $\mathrm{pH}$ on uptake per cent of lead, cadmium and zinc adsorbed from their solutions $(1 \mathrm{mg} / \mathrm{L})$ by clay using $\mathrm{v} / \mathrm{m}$ ratio of $50 \mathrm{ml} / \mathrm{g}$ after $180 \mathrm{~min}$, contact time

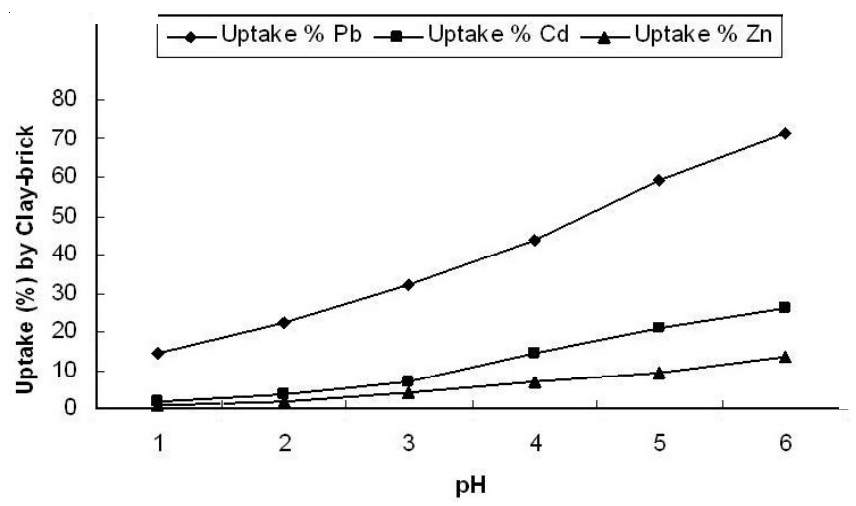

Fig. 6. Effect of $\mathrm{pH}$ on uptake per cent of lead, cadmium and zinc adsorbed from their solutions $(1 \mathrm{mg} / \mathrm{L})$ by clay-brick using $\mathrm{v} / \mathrm{m}$ ratio of 50 $\mathrm{mL} / \mathrm{g}$ after $180 \mathrm{~min}$ contact time

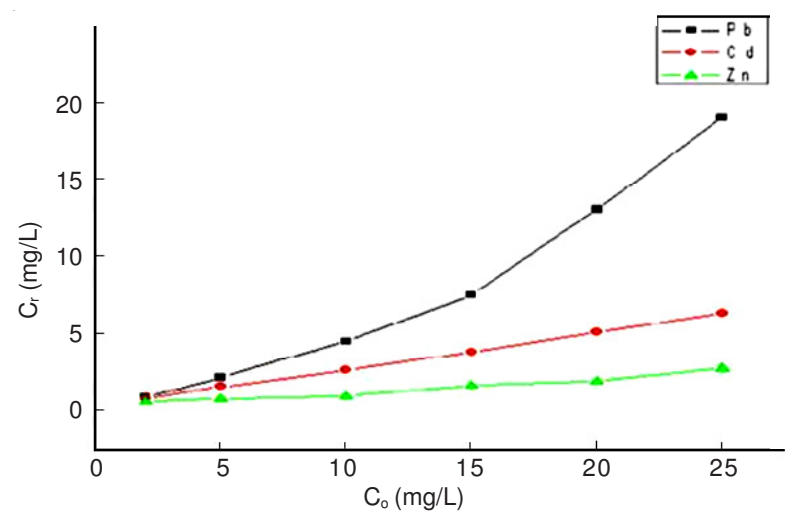

Fig. 7. Effect of metal ion concentration on its uptake by clay-brick $\mathrm{v} / \mathrm{m}=$ $500 \mathrm{~mL} / \mathrm{g}, \mathrm{pH}=6$ and shacking time $9 \mathrm{~h}$

explained by progressive increase in electrostatic mutual interactions between sites that have lower affinity for metal ions as the populations of occupied sites increase ${ }^{29-31}$. A similar trend has been observed in the removal of divalent metal ions ( $\mathrm{Cu}(\mathrm{II}), \mathrm{Cd}(\mathrm{II}), \mathrm{Zn}(\mathrm{II})$ and $\mathrm{Pb}(\mathrm{II})$ ) by plants such as Echornia Speciosa (Nile rose plant) ${ }^{15}$ and P. Lobatu ohwi $(\mathrm{Kudzu})^{32}$. The plots $1 / \mathrm{C}_{\mathrm{r}}=\int(1 / \mathrm{Co})$, for all metal ions, allow us to evaluate the maximum uptake (U \%), as shown in Fig. 8 in the case of clay-brick powder, the maximum uptake value corresponds to $77 \%$ to $\mathrm{Pb}(\mathrm{II}), 25.1 \%$ for $\mathrm{Cd}(\mathrm{II})$ and $8.5 \%$ for $\mathrm{Zn}(\mathrm{II})$. For both adsorbents, the following order is observed for metal ions adsorption: $\mathrm{Pb}$ (II) $>\mathrm{Cd}$ (II) $>\mathrm{Zn}$ (II). Because of the lower hydrated ionic radius of $\mathrm{Pb}$ (II) ions (2.61 $\AA$ ),

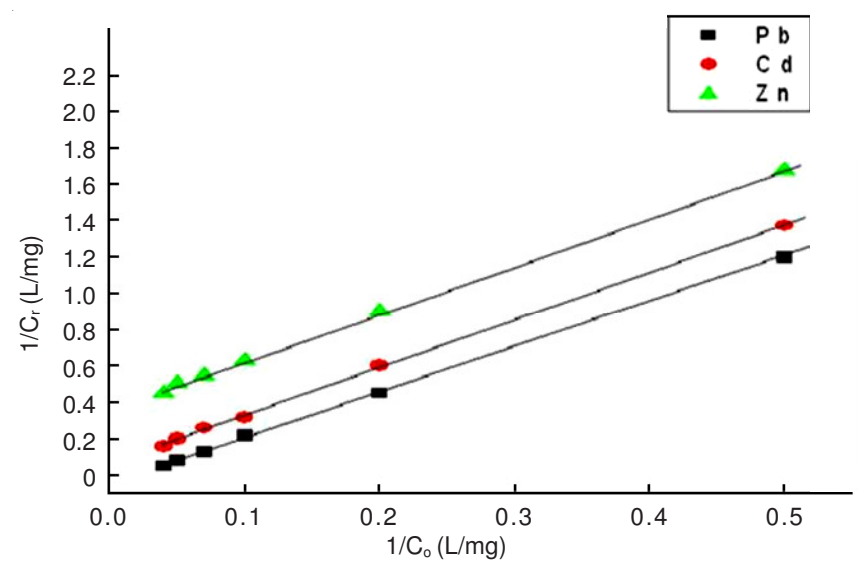

Fig. 8. Plot of inverse value of $\mathrm{Cr}$ versus $\mathrm{C}_{0}$ corresponding to the data shown in Fig. 7

compared with Cd(II) (2.75 $\AA$ ) and Zn(II) (2.89 ̊) they bear a higher change density which favours attractive electrostatic interactions between the two adsorbents and $\mathrm{Pb}(\mathrm{II})$ ions. The higher change density due to a lower hydrated ionic radius can explain the greater maximum adsorption capacity of $\mathrm{Pb}(\mathrm{II})$ ions. Rivera-Utrilla et al. ${ }^{33}$ and Benhima et al. ${ }^{18}$ found the same order and the same explanation for the adsorption of $\mathrm{Pb}(\mathrm{II})$ and $\mathrm{Cd}(\mathrm{II})$ on the activated carbon and on different types of plant particles.

Application of the two sorbents on wastewater: The synthetic and industrial wastewater samples from Abu-zabaal factory were treated by using the natural clay and fired claybrick powders to remove lead, cadmium and zinc ions. The treatment process was carried out at contact time $160 \mathrm{~min}$ at pH 4 and 6.

The obtained results showed that the uptake percentages by using clay-brick as adsorbent reaches to $71,25.1$ and $8.5 \%$ for lead, cadmium and zinc, respectively; whereas the uptake percentages by using clay powder of reaches 45, 22.9 and $5.2 \%$ for lead, cadmium and zinc, respectively.

\section{Conclusion}

In this work we investigated metal ions adsorption onto natural, low cost and available adsorbents. The two adsorbents are raw clay and clay-brick powders. The uptake percentages obtained for the removal of lead, cadmium and zinc by using clay-brick powder are higher than those obtained by using clay-powder for the same ions at the same conditions. In general, the clay-brick powder possesses higher adsorption ability than that of natural clay powder when applied for the adsorption of lead, cadmium and zinc, from wastewater. This matter can be considered as a suitable means to treat wastewater which contain such ionic species.

\section{REFERENCES}

1. N. Nakada, K. Fukay and Y. Wadd, Bull. Environ. Contam. Toxicol., 22, 21 (1979).

2. D.L. Tsalev and Z.K. Zaprianov, AAS in Occupational and Environmental Health Practice, Boca Raton, FL: CRC Press, edn. 2, Vol. 1, p. 109 (1985)

3. T. Maruyama, S.A. Hannah and J.M. Cohen, J. Water Pollut. Contam. Fed., 47, 440 (1975).

4. K.H. Park, M.A. Park, H. Jang, E.K. Kim and Y.H. Kirn, Anal. Sci. Technol., 12, 196 (1999). 
5. D. Petruzzelli, M. Pagano, G. Triavanti and R. Passino, Solvent Extraction Ion Exchange, 17, 677 (1999).

6. H. Faghihian, M. Ghannadi-Marageh and H. Kazemian, Sep. Sci. Technol., 34, 2275 (1999).

7. A. Vecchio, C. Finoli, D. Di-Simine and V. Andreoni, Fresenius J. Anal. Chem., 361, 338 (1998).

8. R.K. Srivastav, S.K. Gupta, K.D.P. Nigam and P. Vasudevan, Int. J. Environ. Stud., 45, 43 (1993).

9. H. Niu, S.X. Xue, J.H. Wang and B. Volesky, Biotechnol. Bioeng., 42, 785 (1993).

10. M. Pansini and C. Collella, Desalination, 78, 287 (1990).

11. C. Namasivayam and K. Ranganathan, Water Res., 29, 1737 (1995).

12. M. Laumakis, P.J. Martin, S. Pamucku and K. Owens, 'Proceeding of the International Conference on Hazard Waste Management, ASCE, New York, p. 528 (1995).

13. C.N. Hewitt, P.J. Metcalfe and R.A. Street, Water Res., 25, 91 (1991)

14. B.E. Reed, S. Arunachalam and B. Thomas, Environ. Progr., 13, 60 (1994).

15. S.H. Abdel-Halim, A.M.A. Shehata and M.F. El-Shahat, Water Res., 37, 1678 (2003).

16. M. Yaman, Anal. Biochem., 339, 1 (2005).

17. B.F. Senkal, M. Ince, E. Yavuz and M. Yaman, Talanta, 72, 962 (2007).

18. H. Benhima, M. Chiban, F. Sinan, P. Seta and M. Persin, Colloid. Surf. B: Biointerf., 61, 10 (2008).

19. M. Kazripour, M. Ansari, S. Tajobehkar, M. Zadeh and H. Reihani Kermani, J. Hazard. Mater., 150, 322 (2008).
20. D.M. Dong, Y. Li, J.J. Zhang and X.Y. Hua, Chemosphere, 57, 369 (2003).

21. S.S. Gupta and K.G. Bhattacharyya, J. Colloid Interf. Sci., 295, 21 (2006).

22. T. Vengrist, R. Binkien and A. Sveikanskait, Appl. Clay Sci., 18, 183 (2001).

23. N.T. Abdel-Ghani, M. Hefny and Gh. A.F. El-Ghaghby, Int. J. Environ. Sci. Technol., 4, 67 (2007).

24. H. Cesura and N. Balkayab, Chem. Eng. J., 131, 203 (2007).

25. S.H. Abdel-Halim, A.M.A. Shehata and M.F. El-Shahat, Bull. Environ. Contam. Toxicol., 74, 78 (2005).

26. S.H. Abdel-Halim, A.M.A. Shehata and M.F. El-Shahat, Bull. Environ. Contam. Toxicol., 70, 262 (2003).

27. B. Salamatinia, A.H. Kamaruddin and A.Z. Abdullah, Chem. Eng. J., 156, 141 (2010).

28. K.Q. Li, Z. Zheng, J.W. Feng, J.B. Zhang, X.Z. Luo, G.H. Zhao and X.F. Huang, J. Hazard. Mater., 166, 1180 (2009).

29. S. Al-Asheh and Z. Duznjak, J. Hazard. Matter., 56, 35 (1997).

30. P. Vancutsem, M.M. Metdagh, P.G. Rouxhet and C. Gillet, React. Polym., 2, 31 (1984).

31. S. Al-Asheh, F. Banat and F. Mohai, Chemosphere, 39, 2087 (1999).

32. P.A. Brown, J.M. Brown and S.J. Allen, Bioresour. Technol., 78, 195 (2001).

33. J. Rivera-Utrilla, I. Bantista-Toledo, M.A. Ferro-Garica and C. MorenoCastiller, Carbon, 41, 323 (2003). 